Article

\title{
Quality of Peri-Urban Soil Developed from Ore-Bearing Carbonates: Heavy Metal Levels and Source Apportionment Assessed Using Pollution Indices
}

\author{
Katarzyna Sutkowska ${ }^{1, *}$, Leslaw Teper ${ }^{1}$, Tomasz Czech $^{2}{ }^{2}$, Tomasz Hulok ${ }^{1}$, Michał Olszak $^{1}$ \\ and Jan Zogala ${ }^{1}$ \\ 1 Institute of Earth Sciences, University of Silesia in Katowice, Bedzinska 60, 41-200 Sosnowiec, Poland; \\ leslaw.teper@us.edu.pl (L.T.); Thulok@op.pl (T.H.); michal.olszak@outlook.com (M.O.); \\ jan_zogala@o2.pl (J.Z.) \\ 2 Department of Agricultural and Environmental Chemistry, University of Agriculture in Krakow, \\ Aleja Adama Mickiewicza 21, 31-120 Kraków, Poland; Tomasz.Czech@ur.krakow.pl \\ * Correspondence: katarzyna.sutkowska@us.edu.pl
}

Received: 20 November 2020; Accepted: 16 December 2020; Published: 19 December 2020

\begin{abstract}
Pollution indices are used to assess the influence of the bedrock as a natural source of heavy-metal $(H M)$, and anthropogenic pollution from ore mining in soils developed from ore-bearing carbonates. The research was conducted in two areas differing in geological setting and type of land use in the Upper Silesia Industrial Region, Southern Poland. Physical properties such as $\mathrm{pH}$, total sulfur, total carbon and total organic carbon values, as well as total $\mathrm{Zn}, \mathrm{Pb}$, and $\mathrm{Cd}$ contents (ICP-OES) for 39 topsoil samples were measured. Contamination factor $\left(C_{f}\right)$, degree of contamination $\left(C_{\text {deg }}\right)$, pollution load index $(P L I)$ and geoaccumulation index $\left(I_{g e o}\right)$, were used to determine the deterioration of topsoil due to $H M$ pollution. The $H M$ content exceeded geochemical background levels by 2.5-18.1 times. Very high to moderate topsoil contamination was determined. In a shallow historical mining zone, the relative influence of particular $H M$ was found to be in the order of $\mathrm{Pb}>$ $\mathrm{Cd}>\mathrm{Zn}$ and, in a deep mining zone, $\mathrm{Zn}>\mathrm{Cd}>\mathrm{Pb}$. In the topsoil developed over shallow ore bodies, the $H M$ content was mainly $(60 \%)$ due to naturally occurring $H M$. In the area of deeply buried ore bodies, $90 \%$ of the $H M$ load was related to anthropogenic sources. $\mathrm{Zn}, \mathrm{Pb}$ and $\mathrm{Cd}$ vertical distributions and the patterns of topsoil pollution differ in terms of types of mined ores, mining methods and times elapsed since mining ceased. Pollution indices are an efficient tool for distinguishing soil anthropogenic pollution and geogenic contamination.
\end{abstract}

Keywords: pollution indices; heavy metals; soil contamination; geogenic and anthropogenic origin

\section{Introduction}

Heavy metals (HM) in the environment originate from geological, industrial, agricultural, atmospheric, and waste sources. Soil is one of the most important environmental components at risk of $H M$ contamination as a result of anthropogenic activities. A high concentration of HMs and metalloids $(\mathrm{Zn}, \mathrm{Pb}, \mathrm{Cd}, \mathrm{As}, \mathrm{Tl}$, etc.) can be found in and around active and abandoned mines or smelting plants [1-3] due to the emission and dispersion of pollutants into air [4,5], water [6,7], soil [8-17], plants [4,18-22], and fauna [23,24]. The global average concentration of $H M$ s in soils varies for $\mathrm{Zn}$ (10-300 $\left.\mathrm{mg} \cdot \mathrm{kg}^{-1}\right), \mathrm{Pb}\left(10-150 \mathrm{mg} \cdot \mathrm{kg}^{-1}\right)$ and $\mathrm{Cd}\left(0.06 \mathrm{mg} \cdot \mathrm{kg}^{-1}\right)$ [25]. In general, the HM concentrations in soils are increasing over time, and the highest concentrations are observed in industrial cities, due to traffic, power plants, and other industrial activities [25]. Soil contains baseline or background 
concentrations of $H M$. The HM content is determined by the composition of the parent rock material from which the soil is derived.

The effective assessment of soil $H M$ contamination is an important global issue [10,25-29]. Indicators for the geochemical assessment of the soil environment include contamination factor $\left(C_{f}\right)$, degree of contamination $\left(C_{d e g}\right)$, pollution load index $(P L I)$, and geoaccumulation index $\left(I_{g e o}\right)$. These indicators enable the estimation of environmental risk and soil degradation due to accumulation of HMs [28-30]. Moreover, they facilitate differentiation between the accumulation of HMs produced by natural processes and anthropogenic activities (e.g., [31]). Essential to any assessment of the degree of soil contamination is the selection of an appropriate reference value. Although this issue has already been widely discussed [26,32-36], there is still a lack of unambiguous methodological findings.

The aim of the current study is to assess the quality of soil developed from $\mathrm{Zn}$ - $\mathrm{Pb}$ ore-bearing carbonates, in terms of (1) the influence of the bedrock, as a natural/geogenic source of HMs, and (2) anthropogenic pollution from ore mining and processing. We attempted a source apportionment of $H M s$ ( $\mathrm{Zn}, \mathrm{Pb}, \mathrm{Cd}$ ) based on the pollution indices and using the local/on-site geochemical background. The research was carried out on the topsoil layers that are usually expected to accumulate trace elements of anthropogenic origin.

The main novelty of our work consists in taking into account data linking the indices to a broader geological context and mining history which has scarcely been published. We compare two areas located in the same $\mathrm{Zn}$-Pb MVT-type deposit, which differ in terms of types of mined ores, ore-body depth, mining method and the time of mining cessation. The presented approach can be applied to the analyses of environmental risk and HM source apportionment in the abandoned mining sites worldwide.

\section{Study Area}

Two areas located in the north-east part of the Upper Silesia Basin (Figure 2) in the Dlugoszyn and Wilkoszyn Synclines in Jaworzno City were chosen for the study. Both synclines belong to the superior synclinorial structure with an NW-NE trending axis resulting from the Alpine orogenic movements. The inclination of the rock layers varies from $4^{\circ}$ to $15^{\circ} \mathrm{NW}$ in the Dlugoszyn Syncline, and from $4^{\circ}$ to $20^{\circ} \mathrm{SE}$ in the North-West limb of the Wilkoszyn Syncline. These tectonic structures comprise the Middle Triassic carbonate formation, which is composed of dolomites, limestones, and marls. The carbonate rock profile is partially altered due to the epigenetic fluid flow resulting in dolomitisation [37]. The $\mathrm{Zn}-\mathrm{Pb}$ mineralisation followed the dolomitisation episode, which developed the ore-bearing dolomites with $\mathrm{Zn}-\mathrm{Pb}$ ore deposits [38]. The $\mathrm{Zn}-\mathrm{Pb}$ ore deposits in the area belong to the stratabound type. The ore minerals (galena, sphalerite, pyrite, marcasite, and secondary nonsulfides) form bodies of varying horizontal- and vertical extension ranging from several tens of centimetres up to several tens of meters. They consist of metasomatic-, dispersed- and cavity-filling-ores, the latter including crusted-, veined-, drusy- and breccia varieties [39]. Most of the ore bodies have a typical tabular form concordant with the rock bedding. The boundaries between the ore-bearing dolomites and the host carbonate rocks are rarely defined, but more commonly form a broad transition zone into weakly mineralized dolostones.

The areas selected for the study vary in terms of the geological setting. In the Dlugoszyn area (see point 1 in Figures 1 and 2), the ore-bearing dolomites occur near the surface (0-1 m), while in the Wilkoszyn syncline (see point 2 in Figures 1 and 2) the ore bodies occur at a depth of 20 to $90 \mathrm{~m}$. The relatively shallow occurrence of ore mineralisation favours the development of mining. There is evidence of outcrop and underground $\mathrm{Zn}-\mathrm{Pb}$ ore mining and smelting from the 12th [40] to the 20th century. The shallow ore exploitation in the Dlugoszyn area was completed at the end of the 19th century, while the deep mines and processing plants in the Wilkoszyn area were abandoned in the middle of the 20th century [41,42]. There is evidence of the historical mining and industrial activity in the landscape of the town [43]. Local ore mining left its mark on natural habitats impacting air [44], water $[45,46]$ and soil $[2,3,47-49]$ quality and imposing imprints onto flora $[50,51]$ and fauna $[52,53]$. 


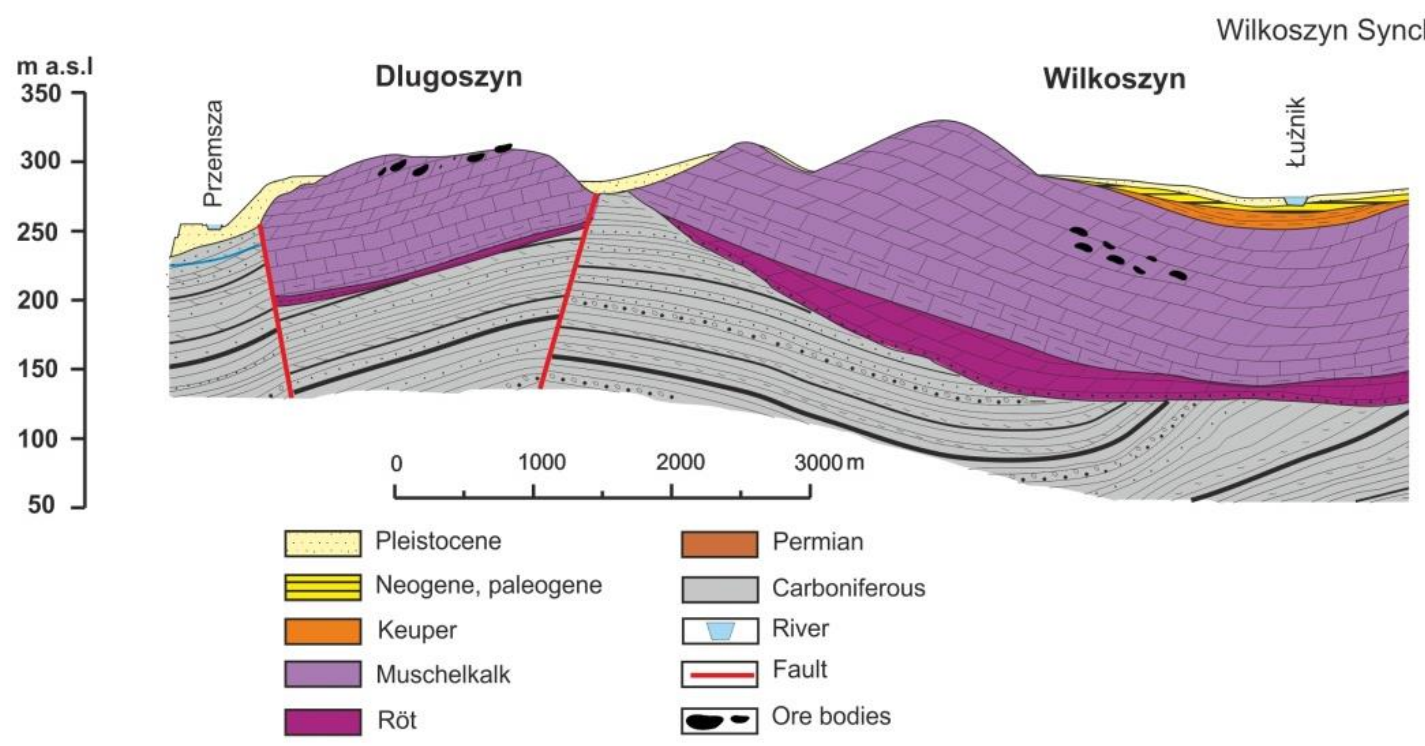

Figure 1. Schematic geological cross-section of the study area showing location of ore bodies, without Quaternary sediments (after [54]).

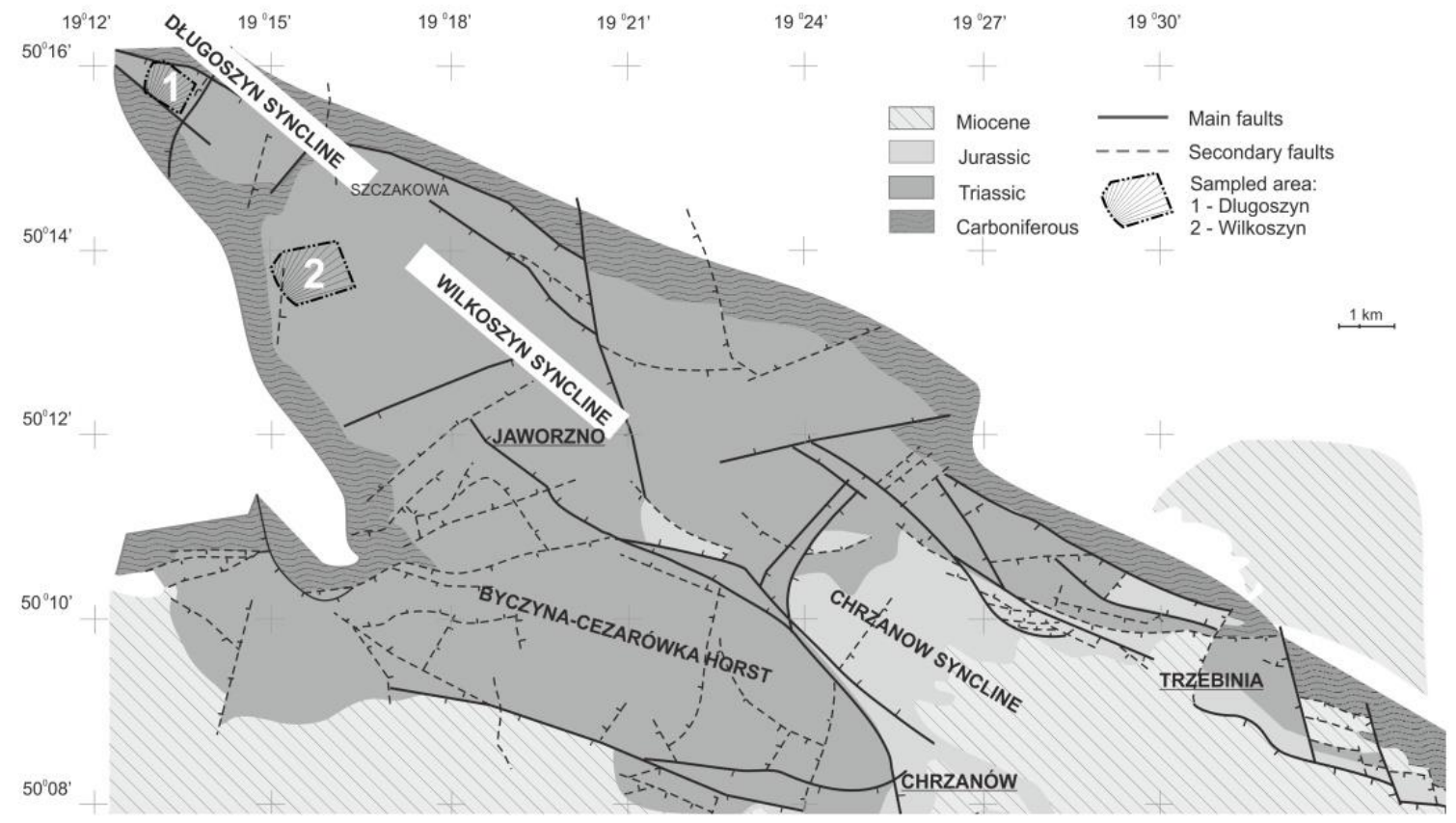

Figure 2. Geological context of the study area, without Quaternary sediments (after [54]).

\section{Material and Analytical Methods}

To investigate the relationship between the ore-bearing bedrock and content of $\mathrm{HMs}(\mathrm{Zn}, \mathrm{Pb}$, and $\mathrm{Cd}$ ) in the soils (mostly skeletal Rendzic Leptosol), 15 soil profiles were studied (Figure 3). We tried to select homogenous soil profiles. Each soil profile was divided into separate horizons, providing 54 soil samples. Only the topsoil layers (up to $30 \mathrm{~cm}$ depth), characterised by the highest concentrations of $H M$, were considered further; these are represented by 39 soil samples in Table 1 . Moreover, bedrock specimens (from each study area) were sampled and analysed to evaluate the local/natural chemical pedogenic enrichment. 
Table 1. Geochemical properties of the topsoil samples. D—Dlugoszyn area, W-Wilkoszyn area.

\begin{tabular}{|c|c|c|c|c|c|c|c|c|c|c|}
\hline \multirow{2}{*}{ Sample Point } & \multirow{2}{*}{ Coordinates } & \multirow{2}{*}{$\begin{array}{l}\text { Sample } \\
\text { Number }\end{array}$} & \multirow{2}{*}{$\begin{array}{c}\text { Depth } \\
{[\mathrm{cm}]}\end{array}$} & \multirow{2}{*}{$\mathrm{pH}$} & \multirow{2}{*}{$\begin{array}{l}\text { TC } \\
{[\%]}\end{array}$} & \multirow{2}{*}{$\begin{array}{l}\text { TOC } \\
{[\%]}\end{array}$} & \multirow{2}{*}{$\begin{array}{l}\text { TS } \\
{[\%]}\end{array}$} & \multicolumn{3}{|c|}{ HM Content $\left[\mathrm{mg} \cdot \mathrm{kg}^{-1}\right]$} \\
\hline & & & & & & & & $\mathrm{Zn}$ & $\mathbf{P b}$ & $\mathrm{Cd}$ \\
\hline D1 & $\begin{array}{c}50^{\circ} 14^{\prime} 19.2^{\prime \prime} \mathrm{N} \\
19^{\circ} 14^{\prime} 30^{\prime \prime} \mathrm{E}\end{array}$ & a & $0-2$ & 6.40 & 10.08 & 9.83 & 0.11 & $3329 \pm 84$ & $1674 \pm 30$ & $37.58 \pm 3.27$ \\
\hline \multirow{2}{*}{ D2 } & \multirow{2}{*}{$\begin{array}{l}50^{\circ} 14^{\prime} 58.5^{\prime \prime} \mathrm{N} \\
19^{\circ} 14^{\prime} 18.7^{\prime \prime} \mathrm{E}\end{array}$} & a & $0-2$ & 4.26 & 20.92 & 20.92 & 0.14 & $701 \pm 17$ & $341 \pm 6$ & $11.75 \pm 0.56$ \\
\hline & & $\mathrm{b}$ & $2-9$ & 5.26 & 9.88 & 9.88 & 0.08 & $907 \pm 8$ & $353 \pm 3$ & $14.72 \pm 0.36$ \\
\hline \multirow{3}{*}{ D3 } & \multirow{3}{*}{$\begin{array}{c}50^{\circ} 15^{\prime} 7.2^{\prime \prime} \mathrm{N} \\
19^{\circ} 14^{\prime} 25^{\prime \prime} \mathrm{E}\end{array}$} & a & $0-3$ & 6.04 & 22.01 & 21.22 & 0.13 & $1438 \pm 66$ & $234 \pm 12$ & $7.46 \pm 0.51$ \\
\hline & & $\mathrm{b}$ & $3-11$ & 6.65 & 9.89 & 7.38 & 0.04 & $1291 \pm 14$ & $329 \pm 0.2$ & $11.29 \pm 0.05$ \\
\hline & & c & $11-22$ & 7.03 & 2.06 & 1.72 & 0.01 & $1170 \pm 21$ & $248 \pm 0.3$ & $6.99 \pm 0.07$ \\
\hline D4 & $\begin{array}{c}50^{\circ} 15^{\prime} 7.1^{\prime \prime} \mathrm{N} \\
19^{\circ} 14^{\prime} 33^{\prime \prime} \mathrm{E}\end{array}$ & a & $0-2$ & 6.41 & 8.55 & 8.50 & 0.07 & $1113 \pm 12$ & $275 \pm 3$ & $9.59 \pm 0.45$ \\
\hline \multirow[t]{2}{*}{ D5 } & \multirow{2}{*}{$\begin{array}{l}50^{\circ} 15^{\prime} 18.2^{\prime \prime} \mathrm{N} \\
19^{\circ} 14^{\prime} 25.6^{\prime \prime} \mathrm{E}\end{array}$} & $\mathrm{b}$ & $2-14$ & 6.06 & 7.16 & 7.16 & 0.07 & $797 \pm 18$ & $267 \pm 2$ & $10.45 \pm 0.04$ \\
\hline & & c & 14-19 & 5.96 & 0.20 & 0.20 & 0.00 & $68 \pm 8$ & $18 \pm 2$ & $0.31 \pm 0.01$ \\
\hline \multirow{2}{*}{ W1 } & \multirow{2}{*}{$\begin{array}{l}50^{\circ} 13^{\prime} 36.1^{\prime \prime} \mathrm{N} \\
19^{\circ} 16^{\prime} 48.3^{\prime \prime} \mathrm{E}\end{array}$} & a & $0-2$ & 6.74 & 5.76 & 5.76 & 0.06 & $2975 \pm 45$ & $440 \pm 2$ & $26.83 \pm 0.23$ \\
\hline & & $\mathrm{b}$ & $2-18$ & 6.97 & 3.40 & 3.40 & 0.04 & $3077 \pm 54$ & $456 \pm 1$ & $27.66 \pm 0.13$ \\
\hline \multirow{2}{*}{ W2 } & \multirow{2}{*}{$\begin{array}{l}50^{\circ} 13^{\prime} 36.2^{\prime \prime} \mathrm{N} \\
19^{\circ} 16^{\prime} 58.1^{\prime \prime} \mathrm{E}\end{array}$} & a & $0-2$ & 6.93 & 11.57 & 11.08 & 0.10 & $1861 \pm 4$ & $673 \pm 8$ & $14.45 \pm 0.25$ \\
\hline & & $\mathrm{b}$ & $2-17$ & 7.36 & 6.24 & 5.07 & 0.05 & $1831 \pm 9$ & $711 \pm 6$ & $11.86 \pm 0.19$ \\
\hline & & a & $0-2$ & 6.34 & 9.22 & 9.22 & 0.07 & $2455 \pm 34$ & $885 \pm 13$ & $17.93 \pm 0.14$ \\
\hline W3 & $\begin{array}{l}50^{\circ} 13^{\prime} 28.6^{\prime \prime} \mathrm{N} \\
19^{\circ} 16^{\prime} 58.7^{\prime \prime} \mathrm{E}\end{array}$ & $\mathrm{b}$ & $2-12$ & 6.67 & 7.47 & 7.47 & 0.07 & $2761 \pm 34$ & $1035 \pm 18$ & $21.44 \pm 0.34$ \\
\hline & & c & $12-24$ & 6.69 & 0.68 & 0.68 & 0.01 & $1388 \pm 2$ & $658 \pm 14$ & $3.30 \pm 0.01$ \\
\hline JWG & $50^{\circ} 13^{\prime} 9^{\prime \prime} \mathrm{N}$ & a & $0-3$ & 6.21 & 2.04 & 2.04 & 0.02 & $630 \pm 15$ & $290 \pm 4$ & $6.28 \pm 0.29$ \\
\hline Wo & $19^{\circ} 16^{\prime} 11^{\prime \prime} \mathrm{E}$ & $\mathrm{b}$ & 3-11 & 6.40 & 1.65 & 1.65 & 0.02 & $583 \pm 17$ & $275 \pm 5$ & $4.34 \pm 0.01$ \\
\hline & & a & $0-3$ & 6.99 & 6.33 & 6.11 & 0.07 & $1063 \pm 11$ & $289 \pm 1$ & $5.81 \pm 0.14$ \\
\hline W7 & $\begin{array}{l}50^{\circ} 13^{\prime} 8^{\prime \prime} \mathrm{N} \\
19^{\circ} 15^{\prime} 56^{\prime \prime} \mathrm{E}\end{array}$ & $\mathrm{b}$ & 3-19 & 7.00 & 3.79 & 3.70 & 0.05 & $1169 \pm 1$ & $307 \pm 2$ & $7.09 \pm 0.02$ \\
\hline & & c & $19-26$ & 7.20 & 1.45 & 1.17 & 0.01 & $639 \pm 1$ & $118 \pm 1$ & $2.34 \pm 0.01$ \\
\hline Wt8 & $50^{\circ} 13^{\prime} 15^{\prime \prime} \mathrm{N}$ & a & $0-4$ & 6.47 & 3.44 & 3.44 & 0.04 & $1003 \pm 3$ & $242 \pm 1$ & $4.38 \pm 0.03$ \\
\hline W8 & $19^{\circ} 15^{\prime} 56^{\prime \prime} \mathrm{E}$ & $\mathrm{b}$ & $4-20$ & 6.50 & 2.78 & 2.78 & 0.03 & $1080 \pm 7$ & $298 \pm 1$ & $6.05 \pm 0.02$ \\
\hline & $50^{\circ} 13^{\prime} 15^{\prime \prime} \mathrm{N}$ & $\mathrm{a}$ & $0-3$ & 6.01 & 1.59 & 1.59 & 0.02 & $480 \pm 9$ & $146 \pm 5$ & $3.90 \pm 0.04$ \\
\hline vo & $19^{\circ} 16^{\prime} 10^{\prime \prime} \mathrm{E}$ & $\mathrm{b}$ & $3-13$ & 6.12 & 1.60 & 1.60 & 0.02 & $497 \pm 2$ & $169 \pm 1$ & $3.95 \pm 0.01$ \\
\hline W10 & $50^{\circ} 13^{\prime} 25^{\prime \prime} \mathrm{N}$ & a & $0-3$ & 6.53 & 2.34 & 2.34 & 0.02 & $652 \pm 7$ & $207 \pm 2$ & $3.71 \pm 0.01$ \\
\hline wo & $19^{\circ} 15^{\prime} 59^{\prime \prime} \mathrm{E}$ & $\mathrm{b}$ & $3-17$ & 6.56 & 2.31 & 2.31 & 0.03 & $727 \pm 3$ & $219 \pm 1$ & $4.20 \pm 0.02$ \\
\hline
\end{tabular}

Prior to the analysis, the soil samples were oven-dried at $105^{\circ} \mathrm{C}$ to constant weight, sieved to $2 \mathrm{~mm}$ through a stainless-steel sieve, and milled into a fine powder, while the bedrock samples were crushed and ground. The soil $\mathrm{pH}$ was determined using a 1:5 (g:mL) ratio of soil and $1 \mathrm{M} \mathrm{KCl}$ solution, with $\mathrm{pH}$ meter ELMETRON CP-315 m. The concentration of total carbon (TC), total organic carbon (TOC), and total sulfur (TS) were determined using an Eltra CS-530 IR-analyser with a TIC module. In order to determine the total content of $\mathrm{Zn}, \mathrm{Pb}$, and $\mathrm{Cd}$, the soil and rock samples were wet digested in a closed system in a mixture of $6 \mathrm{~cm}^{3}$ of concentrated nitric acid (65\% Suprapur), and $2 \mathrm{~cm}^{3}$ of hydrochloric acid (30\% Suprapur). Digestion proceeded with the use of a Perkin Elmer Multiwave 3000 Microwave Digestion, in two steps according to the program of mineralisation recommended by the manufacturer-power: $1400 \mathrm{~W}$, recovery time: $5 \mathrm{~min}$, hold: $25 \mathrm{~min}$ in the first step, $10 \mathrm{~min}$ in the second, fan speed: 1 in the first step, 3 in the second. After mineralisation, the samples were transferred to measuring flasks $\left(10 \mathrm{~cm}^{3}\right)$ with a $1 \%$ solution of Suprapur nitric acid. The HM content 
in the prepared solution was determined using an atomic emission spectrometer ICP-OES Optima 7300 Dual View Perkin Elmer. Each sample was analysed twice. The quality control procedure was performed using internal laboratory standard for soil material. The percentage recovery for observed elements ranged from $86.5 \%$ to $100 \%$ (Supplementary Materials Table S1). The ICP-OES analyses were performed at the Department of Agricultural and Environmental Chemistry, University of Agriculture in Krakow.

\section{Profile D5}

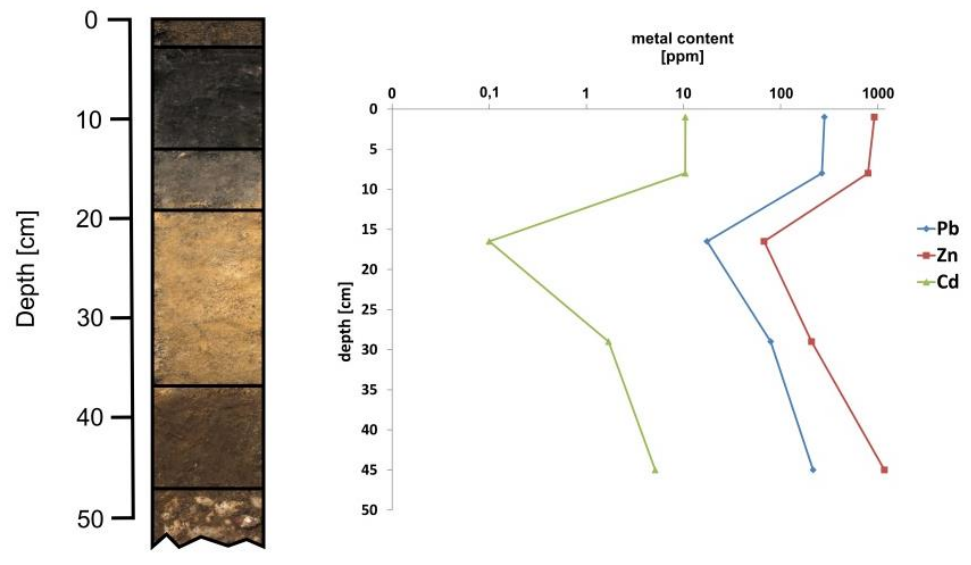

\section{Profile W3}

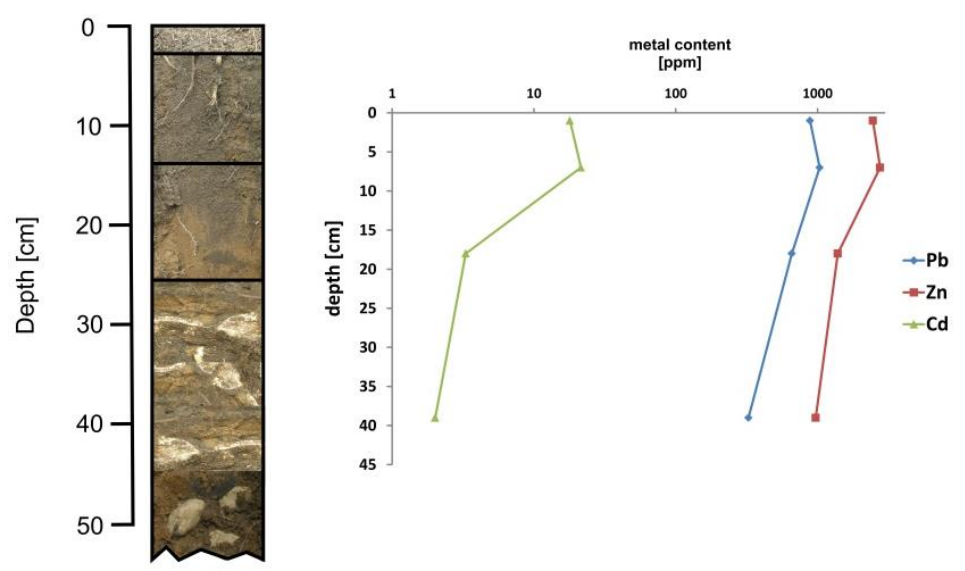

Figure 3. Characteristic examples of studied soil profiles in elevated- (profile D5) and buried (profile W3) ore-bearing dolomitic areas (photographs: T. Hulok).

The phase composition was provided by X-ray diffraction (XRD). The analyses were performed on powdered samples using a PANalytical X'Pert Pro MPD (multipurpose diffractometer) powered by a Philips PW3040/60 X-ray generator and fitted with a 1D silicon strip detector (X'Celerator). The measurements were performed using Co K $\alpha$-radiation with a wavelength of $0.1789010 \mathrm{~nm}$, an acceleration voltage of $40 \mathrm{kV}$, a current of $40 \mathrm{~mA}$, and with $0.02^{\circ} 2 \theta$ step sizes between the angles of $5^{\circ}$ and $70^{\circ} 2 \theta$ and a $300 \mathrm{~s}$ measurement time per step. The data obtained were processed using HighScore+ software and the ICSD database and PDF4+ ICDD database. All XRD analyses were performed at the Institute of Earth Sciences, Faculty of Natural Sciences, University of Silesia, Sosnowiec. 


\section{Soil Pollution Assessment}

The concentration of HMs in the soil is related either to the natural abundance if they come from parent rocks or the anthropogenic load if they come from mining- and processing activities. The distinction between the background of the site level and the pollution load is essential to determine the nature of any anomaly, especially in industrial areas such as the selected study area.

The $H M$ contamination in the soil samples is evaluated by applying the $C_{f}, C_{d e g}, P L I$, and $I_{g e o}$.

The $C_{f}$ is employed to determine the degree of soil pollution with a particular potentially toxic element. The calculation of this factor follows Håkonson's [55] definition (Equation (1)):

$$
C_{f}=\frac{C_{H M}}{C_{B}},
$$

where $C_{H M}$ is the $H M$ concentration in soil samples $\left(\mathrm{mg} \cdot \mathrm{kg}^{-1}\right)$ and $C_{B}$ is reference concentration of HMs in soil in the study area $\left(\mathrm{mg} \cdot \mathrm{kg}^{-1}\right)$. According to Håkonson [55], four contamination categories can be distinguished: $C_{f}<1$, low; $1<C_{f}<3$, moderate; $3<C_{f}<6$, considerable; and $C_{f}>6$, very high contamination.

The estimation of the degree of total contamination of surface layers in a particular core or sampling site was proposed by Håkanson [55] as a sum of the $C_{f}$ for each sample, or $C_{\text {deg }}$ (Equation (2)):

$$
C_{\text {deg }}=\sum_{i=1}^{i=n} C_{f},
$$

The classification of the $C_{\text {deg }}$ in sediments is as follows [55]: $C_{d e g}<6$, low; $6<C_{d e g}<12$, moderate; $12<C_{\text {deg }}<24$, considerable; and $C_{\text {deg }}>24$, high.

The status of the HM pollution in the studied soils is assessed through the PLI [56]. The PLI is calculated by obtaining the $n$-root from the product of $n$ - $C_{f} s$ for all the HMs, where $\mathrm{n}$ is the number of HMs studied (Equation (3)):

$$
P L I=\sqrt[n]{\left(C F_{H M 1} \times C F_{H M 2} \ldots \times C F_{H M n}\right)},
$$

A $P L I$ value $<1$ indicates minimal or no metal pollution, a $P L I=1$ indicates that the level of pollutants is equal to the baseline content of $H M$, whereas $P L I>1$ means that there is pollution and the value indicates the severity of the pollution. For the latter case, Zhang et al. [57] classify soils into the following five categories: $1<P L I<2$, moderately; $2<P L I<3$, moderately to highly; $3<P L I<4$, highly $4<P L I<5$, very highly; and $P L I>5$, extremely polluted.

The $I_{\text {geo }}$ proposed by Müller [58] is a common criterion to evaluate the $H M$ pollution in sediments/soil. It is defined as follows (Equation (4)):

$$
I_{\text {geo }}=\log _{2}\left(\frac{C_{H M}}{1.5 C_{B}}\right)
$$

where $C_{H M}$ is the $H M$ concentration in soil samples $\left(\mathrm{mg}^{\mathrm{kg}} \mathrm{kg}^{-1}\right) ; C_{B}$ is reference concentration of $H M \mathrm{~s}$ in the soil in the study area $\left(\mathrm{mg} \cdot \mathrm{kg}^{-1}\right)$, and factor 1.5 is incorporated in the relationship to account for possible variation in background data due to the lithogenic effect. Müller [58] distinguished seven classes of soil quality based on $H M$ enrichment: Class $0-I_{\text {geo }}<0$, uncontaminated; Class $1-0<I_{\text {geo }}<1$, uncontaminated to moderately; Class $2-1<I_{\text {geo }}<2$, moderately; Class 3-2 $<I_{\text {geo }}<3$, moderately to highly; Class 4-3 $<I_{\text {geo }}<4$, highly; Class 5-4 $<I_{\text {geo }}<5$, highly to extremely; Class 6-Igeo $>5$, extremely contaminated. Igeo Class 0 suggests the lack of contamination, while the highest Class 6 shows the extreme enrichment of the HMs relative to background values.

The above reference concentration, symbolised as $C_{B}$, depends on the local natural conditions, and differs widely from one geologic unit to another. The metal background depends on the 
composition of the parent rock from which the soil was derived [13]. Thus, use of Clark values or off-site reference methods are obviously not appropriate, especially in assessing weakly contaminated sites [34]. The on-site reference value is more specific and sensitive in the case of trace-element soil contamination [33]. Because of the bedrock of ore-bearing dolomites in the research area, we decided to use the HM content in the carbonate bedrock (Table 2) as a local reference value. In addition, three more off-site reference values (Table 2) were applied to further define the role played by different sources in the topsoil contamination detected.

Table 2. HM concentrations in topsoil samples and baseline CB values ( $\mathrm{mg} \cdot \mathrm{kg}^{-1}$ dry weight).

\begin{tabular}{|c|c|c|c|c|c|c|c|c|}
\hline \multirow[t]{2}{*}{$\begin{array}{l}\text { Sample } \\
\text { Point }\end{array}$} & \multicolumn{3}{|c|}{$\begin{array}{l}\text { Weighted Arithmetic Mean } \\
\text { (mg } \cdot \mathrm{kg}^{-1} \text { Dry Weight) }\end{array}$} & \multicolumn{5}{|c|}{ Statistical Parameters } \\
\hline & $\mathrm{Zn}$ & $\mathrm{Pb}$ & $\mathrm{Cd}$ & & & Zn & $\mathbf{P b}$ & Cd \\
\hline D1 & 3320 & 1861 & 32.82 & \multirow{2}{*}{ content } & $\min$. & 68 & 18 & 0.31 \\
\hline D2 & 558 & 173 & 7.19 & & $\max$ & 3329 & 1877 & 37.58 \\
\hline D3 & 1251 & 275 & 8.62 & \multicolumn{2}{|c|}{$\begin{array}{l}\text { weighted arithmetic } \\
\text { mean }\end{array}$} & 1351 & 550 & 13.01 \\
\hline D4 & 982 & 244 & 8.69 & \multicolumn{2}{|c|}{ median } & 937 & 269 & 9.59 \\
\hline \multirow[t]{2}{*}{ D5 } & 619 & 203 & 7.73 & \multicolumn{2}{|c|}{ standard deviation } & 910 & 535 & 9.83 \\
\hline & & & & \multicolumn{2}{|c|}{$\begin{array}{l}\text { coefficient of } \\
\text { variation }[\%]\end{array}$} & 77 & 123 & 83.29 \\
\hline W1 & 3066 & 454 & 27.57 & & & & & \\
\hline W2 & 1159 & 492 & 7.04 & & & & & \\
\hline W3 & 1032 & 361 & 4.14 & & & & & \\
\hline W4 & 2582 & 432 & 17.45 & & & Zn & $\mathbf{P b}$ & Cd \\
\hline W5 & 1054 & 340 & 7.34 & \multirow{2}{*}{ content } & $\min$. & 480 & 118 & 2.34 \\
\hline W6 & 595 & 279 & 4.87 & & $\max$. & 3077 & 1035 & 27.66 \\
\hline W7 & 1014 & 254 & 5.66 & \multicolumn{2}{|c|}{$\begin{array}{l}\text { weighted arithmetic } \\
\text { mean }\end{array}$} & 1549 & 410 & 10.43 \\
\hline W8 & 1149 & 331 & 4.43 & \multicolumn{2}{|c|}{ median } & 1102 & 317 & 6.68 \\
\hline W9 & 287 & 87 & 2.29 & \multicolumn{2}{|c|}{ standard deviation } & 849 & 232 & 7.53 \\
\hline \multirow[t]{3}{*}{ W10 } & 714 & 217 & 4.11 & \multicolumn{2}{|c|}{$\begin{array}{l}\text { coefficient of } \\
\text { variation [\%] }\end{array}$} & 1102 & 317 & 6.68 \\
\hline & \multicolumn{3}{|c|}{ baseline $C_{B}$ values } & & & & & \\
\hline & Zn & $\mathrm{Pb}$ & $\mathrm{Cd}$ & & & & & \\
\hline 1 & 552 & 61 & 3.41 & \multicolumn{5}{|c|}{ carbonate bedrock for Dlugoszyn area } \\
\hline 2 & 86 & 81 & 1.22 & \multicolumn{5}{|c|}{ carbonate bedrock for Wilkoszyn area } \\
\hline 3 & 104 & 44 & 1.30 & \multicolumn{5}{|c|}{ median for topsoil for S Poland [59] } \\
\hline 4 & 200 & 84 & 2 & \multicolumn{5}{|c|}{ median for topsoil in Cracow-Silesia region [60] } \\
\hline 5 & 48 & 15 & 0.15 & \multicolumn{5}{|c|}{ median for topsoil in Europe [61] } \\
\hline
\end{tabular}

\section{Results and Discussion}

The $\mathrm{pH}$ values of the soil in the Dlugoszyn area (Table 1) fluctuate between 4.26 and 7.24 (median 6.57), while in the Wilkoszyn area, the $\mathrm{pH}$ varies from 6.01 to 7.6 (median 6.77), indicating that the examined soil samples are extremely acidic to slightly alkaline, but mostly neutral. Generally, the $\mathrm{pH}$ value decreases with depth. The TOC values obtained for the soil range from $0.2 \%$ to $23.12 \%$ (median $1.72 \%$ ) in the Dlugoszyn area and from $0.68 \%$ to $13.84 \%$ (median $2.04 \%$ ) in the second study area, while TS varies from 0 to $0.14 \%$ (median $0.01 \%$ ) and 0.01 to $0.12 \%$ (median $0.02 \%$ ), in the two study areas, respectively (Table 1). Both parameters diminish with depth. The TOC levels observed are characteristic for rendzina skeletal soils. 
The concentrations of $\mathrm{Zn}, \mathrm{Pb}$, and $\mathrm{Cd}$ in the soil differ significantly between the elevated (Dlugoszyn) and buried (Wilkoszyn) ore-bearing dolomite areas (Table 2). The Dlugoszyn soil samples contain $68-3329 \mathrm{mg} \cdot \mathrm{kg}^{-1} \mathrm{~d} . \mathrm{m}$. of $\mathrm{Zn}, 18-1877 \mathrm{mg} \cdot \mathrm{kg}^{-1} \mathrm{~d} . \mathrm{m}$. of $\mathrm{Pb}$, and $0.31-37.58 \mathrm{mg} \cdot \mathrm{kg}^{-1} \mathrm{~d} . \mathrm{m}$. of $\mathrm{Cd}$, with weighted arithmetic means $1351 \mathrm{mg} \cdot \mathrm{kg}^{-1}$ d.m., $550 \mathrm{mg} \mathrm{kg}{ }^{-1}$ d.m., and $13.01 \mathrm{mg} \cdot \mathrm{kg}^{-1}$ d.m., respectively. The pollution load of the same elements in the Wilkoszyn area ranges as follows: 480-3077 mg kg ${ }^{-1}$ d.m. for $\mathrm{Zn}, 118-1035 \mathrm{mg} \cdot \mathrm{kg}^{-1} \mathrm{~d}$.m. for Pb, and 2.34-27.66 mg. $\mathrm{kg}^{-1} \mathrm{~d} . \mathrm{m}$. for $\mathrm{Cd}$, with weighted arithmetic means $1549 \mathrm{mg} \cdot \mathrm{kg}^{-1}$ d.m., $410 \mathrm{mg} \cdot \mathrm{kg}^{-1}$ d.m., and $10.43 \mathrm{mg} \cdot \mathrm{kg}^{-1} \mathrm{~d} . \mathrm{m}$., respectively. For the soil derived from ore-bearing dolomites occurring close to the surface in the Dlugoszyn area, the mean concentrations of the studied metals exceed 2.5-, 9- and 3.8-fold of the $\mathrm{Zn}, \mathrm{Pb}$, and $\mathrm{Cd}$ content in bedrock, respectively. For the soil developed in the Wilkoszyn area from deeper ore-bearing dolomites, the mean values calculated are 18.1- (for $\mathrm{Zn}$ ), 5.1- (for Pb), and 8.6-fold (for $\mathrm{Cd}$ ) higher than the baseline level (compare Table 2), indicating intensive soil contamination in both study areas.

The main crystalline phases in the topsoil are in the 79.5-84 wt.\% (Table 3) represented by quartz (Figure 4). Goethite is abundant, especially in the Wilkoszyn area (11.5 wt.\%). The large concentration of dolomite (3-5\%), and some calcite (to $0.5 \mathrm{wt} . \%$ ) were also detected. The K-feldspars (microcline and orthoclase), albite, plagioclases, and kaolinite occur there as the accessory minerals. The low-crystalline goethite $(7.16 \AA$ in Figure 4$)$, is accompanied by amorphous iron oxides or sulfides (marcasite, hematite-2.695 $\AA$ ) and/or iron oxide/hydroxide. Additionally, the pyroxene (augite-diopside) or spinel Zn-Al-Fe family phases were documented by diffraction peak $4.675 \AA$.

Table 3. Semiquantitative mineralogical analysis of XRD results.

\begin{tabular}{lcc}
\hline \multirow{2}{*}{ Mineral Name } & D Area & W Area \\
\cline { 2 - 3 } & \multicolumn{2}{c}{ [\%] } \\
\hline Quartz & 84.0 & 79.5 \\
Dolomite & 4.5 & 3.0 \\
Goethite & 0.5 & 11.5 \\
Microcline & 3.0 & 2.5 \\
Orthoclase & 3.0 & 1.0 \\
Albite & 2.5 & 2.5 \\
Kaolinite & 2.0 & - \\
Calcite & 0.5 & - \\
\hline
\end{tabular}

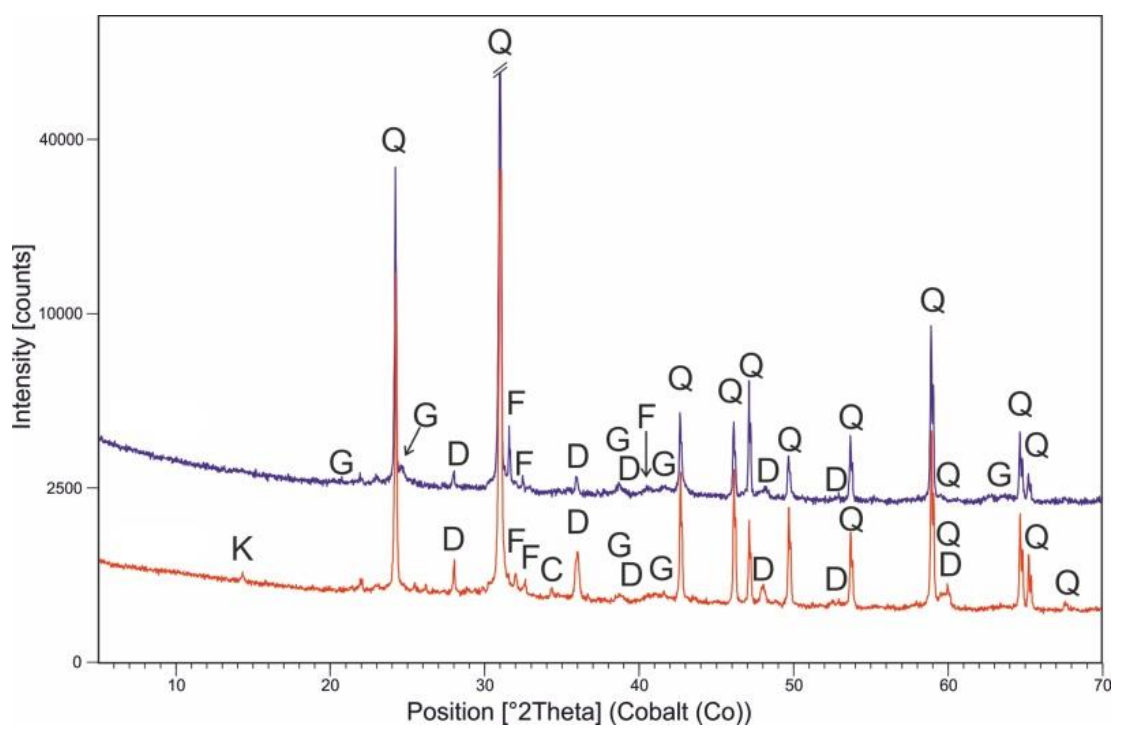

Figure 4. XRD patterns of topsoil from D-Dlugoszyn (red line) and W-Wilkoszyn (blue line) area. Symbol explanations: C—calcite, D—dolomite, F-feldspars, G-goethite, Q-quartz. 
On the basis of the trace-element contents of the sampled soil, the natural concentration and the contamination from anthropogenic sources cannot be distinguished. To assess the degree of anthropogenic influence on the soils, the selected pollution indices $\left(C_{f}, C_{d e g}, P L I\right.$, and $\left.I_{g e o}\right)$ were calculated.

The $C_{f}$ was calculated for each soil sample relative to the bedrock value for both study areas (Table 2). The $C_{f}$ of $\mathrm{Zn}, \mathrm{Pb}$, and $\mathrm{Cd}$ in the Dlugoszyn area is in the range of 1.0-6.0, 2.8-30.6, and 2.1-9.6, with a mean value of 2.4, 9.1, and 3.8, respectively (Table 4). This indicates considerable to very high $(80 \%$ of results for $\mathrm{Pb})$ and moderate to considerable (100\% for $\mathrm{Zn}$ and $80 \%$ for Cd) topsoil contamination level (Table 5). In the Wilkoszyn area, $C_{f}$ has values of 6.9-35.8, 1.1-6.1 and 1.9-22.6 for $\mathrm{Zn}, \mathrm{Pb}$, and $\mathrm{Cd}$, respectively, with a mean value of $14.8,4.1$, and 7.0, respectively (Table 4 ). Such $C_{f}$ levels point to considerable to very high contamination degree with $\mathrm{Zn}(100 \%$ of results) and $\mathrm{Cd}(90 \%)$, and moderate to considerable pollution with $\mathrm{Pb}(80 \%)$ (Table 5).

Table 4. Assessment of $H M$ pollution indices in studied topsoil in relation to the local carbonate bedrock in the D-Dlugoszyn and W-Wilkoszyn areas as a background value.

\begin{tabular}{ccccccccc}
\hline Sample Point & & \multicolumn{1}{c}{$C_{f}$} & & $C_{\text {deg }}$ & PLI & & $I_{\text {geo }}$ & \\
\hline & $\mathbf{Z n}$ & $\mathbf{P b}$ & $\mathbf{C d}$ & & & $\mathbf{Z n}$ & $\mathbf{P b}$ & $\mathbf{C d}$ \\
\hline $\mathrm{D} 1$ & $\mathbf{6 . 0}$ & $\mathbf{3 0 . 6}$ & $\mathbf{9 . 6}$ & $\mathbf{4 6 . 2}$ & $\mathbf{1 2 . 1}$ & 2.0 & 4.3 & 2.7 \\
$\mathrm{D} 2$ & 1.0 & 2.8 & 2.1 & 6.0 & 1.8 & -0.6 & 0.9 & 0.5 \\
$\mathrm{D} 3$ & 2.3 & $\mathbf{4 . 5}$ & 2.5 & 9.3 & 3.0 & 0.6 & 1.6 & 0.8 \\
$\mathrm{D} 4$ & 1.8 & $\mathbf{4 . 0}$ & 2.5 & 8.3 & 2.6 & 0.2 & 1.4 & 0.8 \\
D5 & 1.1 & $\mathbf{3 . 3}$ & 2.3 & 6.7 & 2.0 & -0.4 & 1.2 & 0.6 \\
W1 & $\mathbf{3 5 . 8}$ & $\mathbf{5 . 6}$ & $\mathbf{2 2 . 6}$ & $\mathbf{6 4 . 0}$ & $\mathbf{1 6 . 5}$ & $\mathbf{4 . 6}$ & 1.9 & $\mathbf{3 . 9}$ \\
W2 & $\mathbf{1 3 . 5}$ & $\mathbf{6 . 1}$ & $\mathbf{5 . 8}$ & $\mathbf{2 5 . 4}$ & $\mathbf{7 . 8}$ & $\mathbf{3 . 2}$ & 2.0 & 1.9 \\
W3 & $\mathbf{1 2 . 0}$ & $\mathbf{4 . 5}$ & $\mathbf{3 . 4}$ & $\mathbf{1 9 . 9}$ & $\mathbf{5 . 7}$ & $\mathbf{3 . 0}$ & 1.6 & 1.2 \\
W4 & $\mathbf{3 0 . 1}$ & $\mathbf{5 . 3}$ & $\mathbf{1 4 . 3}$ & $\mathbf{4 9 . 8}$ & $\mathbf{1 3 . 2}$ & $\mathbf{4 . 3}$ & 1.8 & 3.3 \\
W5 & $\mathbf{1 2 . 3}$ & $\mathbf{4 . 9}$ & $\mathbf{6 . 0}$ & $\mathbf{2 3 . 2}$ & $\mathbf{7 . 1}$ & $\mathbf{3 . 0}$ & 1.7 & 2.0 \\
W6 & $\mathbf{6 . 9}$ & $\mathbf{3 . 4}$ & $\mathbf{4 . 0}$ & $\mathbf{1 4 . 4}$ & $\mathbf{4 . 6}$ & $\mathbf{2 . 2}$ & 1.2 & 1.4 \\
W7 & $\mathbf{1 1 . 8}$ & $\mathbf{3 . 1}$ & $\mathbf{4 . 6}$ & $\mathbf{1 9 . 6}$ & $\mathbf{5 . 6}$ & $\mathbf{3 . 0}$ & 1.1 & 1.6 \\
W8 & $\mathbf{1 3 . 4}$ & $\mathbf{4 . 1}$ & $\mathbf{3 . 6}$ & $\mathbf{2 1 . 1}$ & $\mathbf{5 . 8}$ & $\mathbf{3 . 2}$ & 1.4 & 1.3 \\
W9 & $\mathbf{3 . 3}$ & 1.1 & 1.9 & 6.3 & 1.9 & 1.2 & -0.5 & 0.3 \\
W10 & $\mathbf{8 . 3}$ & 2.7 & $\mathbf{3 . 4}$ & $\mathbf{1 4 . 4}$ & $\mathbf{4 . 2}$ & $\mathbf{2 . 5}$ & 0.8 & 1.2 \\
\hline
\end{tabular}

The $C_{\text {deg }}$ index determines the degree of overall contamination of a particular sample in the study areas. Based on the $C_{d e g}$ (see Tables 4 and 5), $80 \%$ of the calculated values for the Dlugoszyn samples are recognised as moderately contaminated, while $20 \%$ are very highly contaminated. In the Wilkoszyn samples, $60 \%$ indicate very high $(30 \%)$ and moderate $(10 \%)$ pollution of the topsoil (Table 5).

The PLI indicates deterioration of the soil quality due to metal pollution. In the current study, the PLI obtained for the Dlugoszyn samples indicates moderate ( $20 \%$ of results), moderate to high $(40 \%)$, high (20\%) and extreme (20\%) topsoil pollution (Table 5), with values ranging from 1.8 to 12.1 , and mean equal to 4.3 (Table 4). In the Wilkoszyn samples, the PLI values range from 1.9 to 16.5 , with a mean of 7.2 (Table 4 ) pointing to extremely ( $70 \%$ of results), very high $(20 \%)$, and moderately $(10 \%)$ polluted topsoil (Table 5).

The pollution indices indicate the moderately to extremely high level of topsoil contamination and reveal a difference in the level of topsoil contamination between the study areas (Table 5). 
Table 5. Percentage of class distribution of topsoil pollution for indices considered. D—Dlugoszyn area, W-Wilkoszyn area.

\begin{tabular}{|c|c|c|c|c|c|c|c|}
\hline \multirow[t]{3}{*}{ Pollution Index } & \multirow[t]{3}{*}{ Classes of Soil Quality } & \multicolumn{6}{|c|}{ Studied Area } \\
\hline & & \multicolumn{3}{|c|}{$\mathbf{D}$} & \multicolumn{3}{|c|}{ W } \\
\hline & & $\mathrm{Zn}$ & $\mathbf{P b}$ & $\mathrm{Cd}$ & Zn & $\mathrm{Pb}$ & $\mathrm{Cd}$ \\
\hline \multirow[t]{4}{*}{$C_{f}[\%]$} & very high contamination & 0 & 20 & 20 & 90 & 10 & 20 \\
\hline & considerable contamination & 20 & 60 & 0 & 10 & 70 & 70 \\
\hline & moderate contamination & 80 & 20 & 80 & 0 & 20 & 10 \\
\hline & low contamination & 0 & 0 & 0 & 0 & 0 & 0 \\
\hline \multirow[t]{4}{*}{$C_{d e g}[\%]$} & very high contamination & & 20 & & & 30 & \\
\hline & considerable contamination & & 0 & & & 60 & \\
\hline & moderate contamination & & 80 & & & 10 & \\
\hline & low contamination & & 0 & & & 0 & \\
\hline \multirow[t]{6}{*}{ PLI [\%] } & extremely high pollution & & 20 & & & 70 & \\
\hline & very high pollution & & 0 & & & 20 & \\
\hline & high pollution & & 20 & & & 0 & \\
\hline & moderate to high pollution & & 40 & & & 0 & \\
\hline & moderate pollution & & 20 & & & 10 & \\
\hline & unpolluted & & 0 & & & 0 & \\
\hline \multirow[t]{7}{*}{$I_{g e o}[\%]$} & Class 6 extremely polluted & 0 & 0 & 0 & 0 & 0 & 0 \\
\hline & Class 5 highly to extremely polluted & 0 & 20 & 0 & 20 & 0 & 0 \\
\hline & Class 4 heavy polluted & 0 & 0 & 0 & 50 & 0 & 0 \\
\hline & Class 3 moderately to heavily polluted & 20 & 0 & 20 & 20 & 10 & 30 \\
\hline & Class 2 moderately polluted & 0 & 60 & 0 & 10 & 70 & 60 \\
\hline & Class 1 unpolluted to moderately polluted & 40 & 20 & 80 & 0 & 10 & 10 \\
\hline & Class 0 unpolluted & 40 & 0 & 0 & 0 & 10 & 0 \\
\hline
\end{tabular}

The $\mathrm{I}_{\text {geo }}$ ranges from -0.6 to 2.0 for $\mathrm{Zn}$, with a mean value of $0.4 ; 0.9$ to 4.3 for $\mathrm{Pb}$, with a mean value of 1.9 , and 0.5 to 2.7 for $C d$, with a mean value of 1.1 in the Dlugoszyn area (Table 4 ). The values of $\mathrm{I}_{\text {geo }}$ for $\mathrm{HMs}$ decrease in the sequence $\mathrm{Pb}>\mathrm{Cd}>\mathrm{Zn}$. The results classify the area as highly polluted with $\mathrm{Pb}$ and moderately polluted with $\mathrm{Zn}$ and $\mathrm{Cd}$ (Table 5). In contrast, in the Wilkoszyn area, the $\mathrm{I}_{\text {geo }}$ varies widely from $1.2-4.6$ for $\mathrm{Zn}$, with mean value $3.0 ;-0.5-2.0$ for $\mathrm{Pb}$, with mean value 1.3 and 0.3-3.9 for $\mathrm{Cd}$, with mean value 1.8 (Table 4). The $H M$ pollution follows the order $\mathrm{Zn}>\mathrm{Cd}>\mathrm{Pb}$. Using $I_{g e o}$, we can determine the potential source of pollution. The $I_{g e o}$ values obtained for the elevated ore-bearing dolomites in the Dlugoszyn area indicate mainly baseline levels of pollution for $\mathrm{Zn}$ and $\mathrm{Cd}$, as $80 \% \mathrm{Zn}$ and $80 \% \mathrm{Cd}$ belong to Classes 0 and 1 . The only exception is pollution with $\mathrm{Pb}$ (see Table 5 ). Most of the $\mathrm{Zn}$ and $\mathrm{Cd}$ are derived from geogenic sources, and most of the $\mathrm{Pb}(80 \%)$ is derived from anthropogenic sources. As such, in the Dlugoszyn area, the deterioration in soil quality is due to $\mathrm{Pb}$. In the Wilkoszyn area, with buried ore-bearing dolomites, moderate to heavy pollution by $\mathrm{Pb}$ and $\mathrm{Cd}$ is observed, as $80 \% \mathrm{~Pb}$ and $90 \% \mathrm{Cd}$ belong to Class 2 and 3 (Table 5). Heavy to extreme pollution by $\mathrm{Zn}$ is identified, as 70\% $\mathrm{Zn}$ belongs to Class 4 and 5 (Table 5). Based on these results and the fact that concentrations of HMs decrease with depth, the HMs in the topsoil of the Wilkoszyn location is of anthropogenic origin. The graphical model of HM immissions into the topsoil of the Dlugoszyn and Wilkoszyn areas is presented in the Figure 5, while the complete set of soil profiles studied is put into the Supplementary Materials (Figure S1).

When calculating pollution indices, the selection of an appropriate reference value is an important and complicated issue. Opinions about the best value to use are divided. Some researchers favour the trace-element contents in the deeper soil horizon $[32,36,62]$ or the average values in soil from the study area $[30,63]$ as correct. Others consider the trace-element contents in the bedrock $[64,65]$ as best. The accuracy and sensitivity of the on-site reference value in identifying trace-element soil contamination was evaluated by Desaules [33]. The specific geological setting of both study areas forced us to calculate the selected pollution indices with reference to the bedrock. 


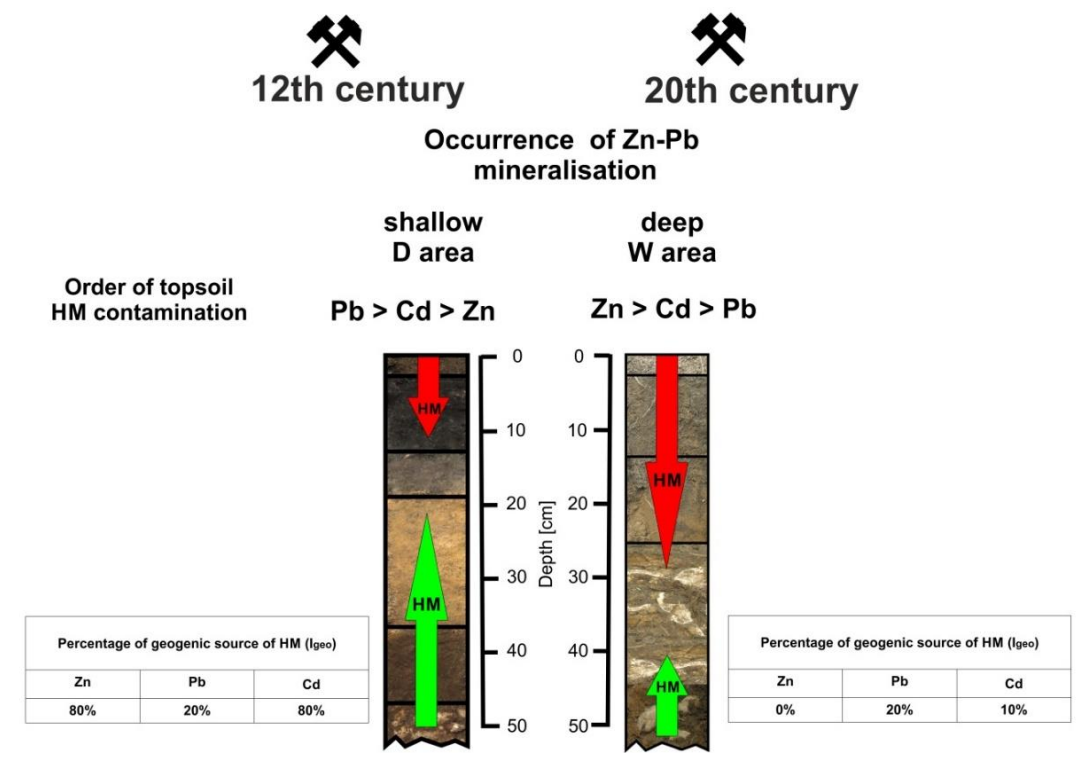

Figure 5. Graphical model of anthropogenic (red arrows) and geogenic (green arrows) HM immissions into the topsoil of the D-Dlugoszyn and W-Wilkoszyn areas.

We also take off-site reference values defined as the median for topsoil in (1) the Cracow-Silesia region [60], (2) S Poland [59] and (3) Europe [61] into consideration. Outcomes of these examination are listed in Tables 6-8. In applying the off-site reference values to topsoil in the area where shallow ore-bearing dolomites occur (the Dlugoszyn area), a significantly higher degree of contamination is observed. Additionally, anthropogenic sources are mainly responsible for the $H M$ presence in the soil. The percentage of class distribution shows (Tables 6-8) that $80-100 \%$ of $I_{\text {geo }}$ values belong to classes 2-6. The only exception refers to $\mathrm{Pb}$ when the S Poland median value is used. In the case of deeper situated $\mathrm{Zn}-\mathrm{Pb}$ mineralization (the Wilkoszyn area), comparable results were obtained using the off-site and on-site reference values. Significant differences were noted when the reference value for European topsoil was considered. Using the latter reference value, the extremely high soil contamination $\left(C_{f}, C_{d e g}\right)$ here is attributed mainly to human activity ( $I_{g e o}$; see Table 8 ). In our opinion, and especially in the case where the ore-bearing dolomite is near surface, use of the local reference value to assess topsoil contamination provides more reliable results than use of off-site reference values.

Table 6. Assessment of HM pollution indices in studied topsoil in relation to the median for topsoil in the Cracow-Silesia region as a background value [60].

\begin{tabular}{|c|c|c|c|c|c|c|c|c|}
\hline Sample Point & & $C_{f}$ & & $C_{d e g}$ & $P L I$ & & $I_{g e o}$ & \\
\hline & $\mathrm{Zn}$ & $\mathrm{Pb}$ & Cd & & & $\mathrm{Zn}$ & $\mathrm{Pb}$ & Cd \\
\hline D1 & 31.9 & 42.3 & 25.2 & 99.5 & 32.4 & 4.4 & 4.8 & 4.1 \\
\hline D2 & 5.4 & 3.9 & 5.5 & 14.8 & 4.9 & 1.8 & 1.4 & 1.9 \\
\hline D3 & 12.0 & 6.3 & 6.6 & 24.9 & 7.9 & 3.0 & 2.1 & 2.1 \\
\hline D4 & 9.4 & 5.6 & 6.7 & 21.7 & 7.1 & 2.7 & 1.9 & 2.2 \\
\hline D5 & 5.9 & 4.6 & 5.9 & 16.5 & 5.5 & 2.0 & 1.6 & 2.0 \\
\hline W1 & 29.5 & 10.3 & 21.2 & 61.0 & 18.6 & 4.3 & 2.8 & 3.8 \\
\hline W2 & 11.1 & 11.2 & 5.4 & 27.7 & 8.8 & 2.9 & 2.9 & 1.9 \\
\hline W3 & 9.9 & 8.2 & 3.2 & 21.3 & 6.4 & 2.7 & 2.5 & 1.1 \\
\hline W4 & 24.8 & 9.8 & 13.4 & 48.1 & 14.8 & 4.0 & 2.7 & 3.2 \\
\hline W5 & 10.1 & 9.1 & 5.6 & 24.9 & 8.0 & 2.8 & 2.6 & 1.9 \\
\hline W6 & 5.7 & 6.3 & 3.7 & 15.8 & 5.1 & 1.9 & 2.1 & 1.3 \\
\hline W7 & 9.7 & 5.8 & 4.4 & 19.9 & 6.3 & 2.7 & 1.9 & 1.5 \\
\hline W8 & 11.0 & 7.5 & 3.4 & 22.0 & 6.6 & 2.9 & 2.3 & 1.2 \\
\hline W9 & 2.8 & 2.0 & 1.8 & 6.5 & 2.1 & 0.9 & 0.4 & 0.2 \\
\hline W10 & 6.9 & 4.9 & 3.2 & 15.0 & 4.7 & 2.2 & 1.7 & 1.1 \\
\hline
\end{tabular}

In bold-strongly contaminated. 
Table 7. Assessment of HM pollution indices in studied topsoil in relation to the median for topsoil in $\mathrm{S}$ Poland as a background value [59].

\begin{tabular}{|c|c|c|c|c|c|c|c|c|}
\hline Sample Point & & $C_{f}$ & & $C_{d e g}$ & $P L I$ & & $I_{g e o}$ & \\
\hline & Zn & $\mathrm{Pb}$ & $\mathrm{Cd}$ & & & $\mathrm{Zn}$ & $\mathrm{Pb}$ & Cd \\
\hline D1 & 16.6 & 22.1 & 16.4 & 55.2 & 18.2 & 3.5 & 3.9 & 3.5 \\
\hline D2 & 2.8 & 2.1 & 3.6 & 8.4 & 2.7 & 0.9 & 0.5 & 1.3 \\
\hline D3 & 6.3 & 3.3 & 4.3 & 13.8 & 4.5 & 2.1 & 1.1 & 1.5 \\
\hline D4 & 4.9 & 2.9 & 4.3 & 12.2 & 4.0 & 1.7 & 1.0 & 1.5 \\
\hline D5 & 3.1 & 2.4 & 3.9 & 9.4 & 3.1 & 1.0 & 0.7 & 1.4 \\
\hline W1 & 5.4 & 13.8 & 15.3 & 34.5 & 10.5 & 3.4 & 1.9 & 3.2 \\
\hline W2 & 5.9 & 3.5 & 5.8 & 15.2 & 4.9 & 2.0 & 2.0 & 1.2 \\
\hline W3 & 4.3 & 2.1 & 5.2 & 11.5 & 3.6 & 1.8 & 1.5 & 0.5 \\
\hline W4 & 5.1 & 8.7 & 12.9 & 26.8 & 8.3 & 3.1 & 1.8 & 2.5 \\
\hline W5 & 4.8 & 3.7 & 5.3 & 13.7 & 4.5 & 1.8 & 1.7 & 1.3 \\
\hline W6 & 3.0 & 3.3 & 2.4 & 8.7 & 2.9 & 1.0 & 1.1 & 0.7 \\
\hline W7 & 5.1 & 3.0 & 2.8 & 10.9 & 3.5 & 1.8 & 1.0 & 0.9 \\
\hline W8 & 5.7 & 3.9 & 2.2 & 11.9 & 3.7 & 1.9 & 1.4 & 0.6 \\
\hline W9 & 1.4 & 1.0 & 1.1 & 3.6 & 1.2 & -0.1 & -0.5 & -0.4 \\
\hline W10 & 3.6 & 2.6 & 2.1 & 8.2 & 2.7 & 1.3 & 0.8 & 0.5 \\
\hline
\end{tabular}

Table 8. Assessment of HM pollution indices in studied topsoil in relation to the median for European topsoil as a background value [61].

\begin{tabular}{|c|c|c|c|c|c|c|c|c|}
\hline Sample Point & & $c_{f}$ & & $C_{d e g}$ & $P L I$ & & $I_{g e o}$ & \\
\hline & Zn & $\mathbf{P b}$ & $\mathrm{Cd}$ & & & $\mathrm{Zn}$ & $\mathbf{P b}$ & Cd \\
\hline D1 & 69.2 & 124.0 & 218.8 & 412.0 & 123.4 & 5.5 & 6.4 & 7.2 \\
\hline D2 & 11.6 & 11.5 & 47.9 & 71.1 & 18.6 & 3.0 & 2.9 & 5.0 \\
\hline D3 & 26.1 & 18.4 & 57.4 & 101.9 & 30.2 & 4.1 & 3.6 & 5.3 \\
\hline D4 & 20.5 & 16.3 & 57.9 & 94.7 & 26.8 & 3.8 & 3.4 & 5.3 \\
\hline D5 & 12.9 & 13.5 & 51.5 & 78.0 & 20.8 & 3.1 & 3.2 & 5.1 \\
\hline W1 & 63.9 & 30.3 & 183.8 & 278.0 & 70.9 & 5.4 & 4.3 & 6.9 \\
\hline W2 & 24.2 & 32.8 & 46.9 & 103.9 & 33.4 & 4.0 & 4.5 & 5.0 \\
\hline W3 & 21.5 & 24.1 & 27.6 & 73.2 & 24.3 & 3.8 & 4.0 & 4.2 \\
\hline W4 & 53.8 & 28.8 & 116.4 & 199.0 & 56.5 & 5.2 & 4.3 & 6.3 \\
\hline W5 & 21.9 & 26.7 & 48.9 & 97.5 & 30.6 & 3.9 & 4.2 & 5.0 \\
\hline W6 & 12.4 & 18.6 & 32.5 & 63.5 & 19.6 & 3.0 & 3.6 & 4.4 \\
\hline W7 & 21.1 & 16.9 & 37.8 & 75.8 & 23.8 & 3.8 & 3.5 & 4.7 \\
\hline W8 & 23.9 & 22.0 & 29.6 & 75.5 & 25.0 & 4.0 & 3.9 & 4.3 \\
\hline W9 & 6.0 & 5.8 & 15.3 & 27.0 & 8.1 & 2.0 & 1.9 & 3.3 \\
\hline W10 & 14.9 & 14.5 & 27.4 & 56.7 & 18.1 & 3.3 & 3.3 & 4.2 \\
\hline
\end{tabular}

Diatta et al. [9] observed similar results, with significantly high $H M$ levels in soils impacted by the Miasteczko Slaskie Zn smelter, in part of the Upper Silesia Industrial Region. The mean $\mathrm{Zn}, \mathrm{Pb}$, and $\mathrm{Cd}$ contents in $\mathrm{mg} \cdot \mathrm{kg}^{-1}$ reported are 1062.97, 781.91, and 12.32, respectively. Using the off-site reference value to $I_{g e o}, C_{f}$, and $C_{\text {deg }}$ calculations, extremely high contamination was observed for $\mathrm{Zn}$, $\mathrm{Cd}$, and $\mathrm{Pb}$, in ascending order [9]. Our findings differ slightly in terms of the influence of particular HMs. In our opinion, the difference between the orders of pollutant intensity acquired for individual sites resulted primarily from the local industrial land use and the kind of reference value.

The historical mining of $\mathrm{Zn}-\mathrm{Pb}$ ores in the Dlugoszyn area was based on the dominant mineral, galena ( $\mathrm{Pb}$ sulfide), which occurs in shallow ore bodies which are easily recognised. Moreover, $\mathrm{Pb}$ has a relatively low melting point, allowing for ease of processing [41]. As such, ore mining in the area started in the early medieval period and resulted in the most severe Pb pollution in the Dlugoszyn topsoil. The levels of $\mathrm{Zn}$ and $\mathrm{Cd}$ are derived from the metal-rich bedrock. 
The very high $\mathrm{Zn}$ and $\mathrm{Pb}$ contamination observed in the Wilkoszyn area probably results from the 20th century underground $\mathrm{Zn}-\mathrm{Pb}$ ore mining and processing, when galena, $\mathrm{Zn}$ sulfides, and nonsulfides were mined and processed in the area. As such, it seems probable that recent industrial operations are a principal cause of the high levels of $\mathrm{Zn}$ and $\mathrm{Pb}$ accumulated in the Wilkoszyn topsoil.

Generally, soil samples from arable fields and home gardens across the Upper Silesia Industrial Region are characterised by high levels of toxic HMs. This is reflected in the HM concentrations in locally cultivated vegetables, which are well above the permissible levels [11]. Both study areas are used as peri-urban agricultural lands. The very high topsoil $H M$ levels reported in this paper are not as harmful due to the $\mathrm{pH}$ value (Table 1) observed in studied soil. The HMs are regarded as highly soluble and more toxic in an acidic soil environment [66,67].

\section{Conclusions}

The application of various pollution indices $\left(C_{f}, C_{\text {deg }}, P L I\right.$, and $\left.I_{g e o}\right)$ and the local background value $C_{B}$ enable the detection of $\mathrm{Zn}, \mathrm{Pb}$, and $\mathrm{Cd}$ pollution in soils. Depending on the index used, we determined very high to considerable (according to the classification proposed by [55]) topsoil contamination. The influence intensity of particular metals differs between studied areas. In the case of shallow historical mining (the Dlugoszyn area), it follows the order $\mathrm{Pb}>\mathrm{Cd}>\mathrm{Zn}$, while in the place of deep mining and processing (the Wilkoszyn area) it decreases in the sequence $\mathrm{Zn}>\mathrm{Cd}>\mathrm{Pb}$. With the geo-accumulation index, it is possible to discriminate between natural and anthropogenic HMs in the soils developed over the ore-bearing formation in the two areas. Based on $I_{g e o}$ values, we consider that the HM content in the topsoil developed over the shallowly occurring ore bodies in dolomites (the Dlugoszyn area) is mainly $(60 \%)$ connected with the natural presence of metals. In the Wilkoszyn area where ore bodies are more deeply buried, $90 \%$ of the $H M$ load is related to anthropogenic sources. An accurate assessment of soil quality, based on HM content, is possible only with the combined use of various pollution indices.

Supplementary Materials: The following are available online at http://www.mdpi.com/2075-163X/10/12/1140/s1, Table S1. $\mathrm{Zn}, \mathrm{Pb}, \mathrm{Cd}$ content $\mathrm{mg} . \mathrm{kg}^{-1} \mathrm{~d}$. m. determined in the internal laboratory standard for soil material $(n=20)$, Figure S1. The complete set of soil profiles for D-Dlugoszyn and W-Wilkoszyn areas.

Author Contributions: Conceptualization: K.S., L.T.; Methodology: K.S.; Investigation: K.S., T.C., T.H., M.O., J.Z.; Formal analysis: K.S.; Resources: T.C.; Writing—original draft: K.S.; Writing—review \& editing: L.T.; Funding acquisition: L.T.; Supervision: L.T.; Data curation and Visualization: K.S. All authors have read and agreed to the published version of the manuscript.

Funding: This study was funded by the University of Silesia, Institute of Earth Sciences (WNP/INOZ/2020_ZB32).

Acknowledgments: This study was undertaken in the framework of the activities of the University of Silesia in Katowice and was funded by the University of Silesia, Institute of Earth Sciences (WNP/INOZ/2020_ZB32). We wish to thank Tomasz Krzykawski from the University of Silesia in Katowice for his assistance with XRD analysis. We are grateful to Pádhraig S. Kennan from University College Dublin for valuable remarks and suggestions. Two anonymous reviewers are thanked for improving the quality of the paper.

Conflicts of Interest: The authors declare no conflict of interest.

\section{References}

1. Norgate, T.E.; Jahanshahi, S.; Rankin, W.J. Assessing the environmental impact of metal production processes of metal production processes. J. Clean. Prod. 2007, 15, 838-848. [CrossRef]

2. Chrastný, V.; Vaněk, A.; Teper, L.; Cabala, J.; Procházka, J.; Pechar, L.; Drahota, P.; Penížek, V.; Komárek, M.; Novák, M. Geochemical position of $\mathrm{Pb}, \mathrm{Zn}$ and $\mathrm{Cd}$ in soils near the Olkusz mine/smelter, South Poland: Effects of land use, type of contamination and distance from pollution source. Environ. Monit. Assess. 2012, 184, 2517-2536. [CrossRef] 
3. Vaněk, A.; Chrastný, V.; Komárek, M.; Penížek, V.; Teper, L.; Cabala, J.; Drábek, O. Geochemical position of thallium in soils from a smelter-impacted area. J. Geochem. Explor. 2013, 124, 176-182. [CrossRef]

4. Kalinovic, T.S.; Serbula, S.M.; Radojevic, A.A.; Kalinovic, J.V.; Steharnik, M.M.; Petrovic, J.V. Elder, linden and pine biomonitoring ability of pollution emitted from the copper smelter and the tailings ponds. Geoderma 2016, 262, 266-275. [CrossRef]

5. Ghayoraneh, M.; Qishlaqi, A. Concentration, distribution and speciation of toxic metals in soils along a transect around a $\mathrm{Zn} / \mathrm{Pb}$ smelter in the northwest of Iran. J. Geochem. Explor. 2017, 180, 1-14. [CrossRef]

6. Varol, M. Assessment of heavy metal contamination in sediments of the Tigris River (Turkey) using pollution indices and multivariate statistical techniques. J. Hazard. Mater. 2011, 195, 355-364. [CrossRef] [PubMed]

7. Ogbeibu, A.E.; Omoigberale, M.O.; Ezenwa, I.M.; Eziza, J.O.; Igwe, J.O. Using pollution load index and geoaccumulation index for the assessment of heavy metal pollution and sediment quality of the Benin River, Nigeria. Nat. Environ. 2014, 2, 1-9. [CrossRef]

8. Loska, K.; Wiechuła, D.; Korus, I. Metal contamination of farming soils affected by industry. Environ. Int. 2004, 30, 159-165. [CrossRef]

9. Diatta, J.B.; Chudzinska, E.; Wirth, S. Assessment of heavy metal contamination of soils impacted by a zinc smelter activity. J. Elementol. 2008, 13, 5-16.

10. Li, Z.; Ma, Z.; van der Kuijp, T.J.; Yuan, Z.; Huang, L. A review of soil heavy metal pollution from mines in China: Pollution and health risk assessment. Sci. Total Environ. 2014, 468-469, 843-853. [CrossRef]

11. Dziubanek, G.; Piekut, A.; Rusin, M.; Baranowska, R.; Hajok, I. Contamination of food crops grown on soils with elevated heavy metals content. Ecotoxicol. Environ. Saf. 2015, 118, 183-189. [CrossRef] [PubMed]

12. Ettler, V. Soil contamination near non-ferrous metal smelters: A review. Appl. Geochem. 2016, 64, 56-74. [CrossRef]

13. Nouri, M.; Haddioui, A. Assessment of metals contamination and ecological risk in ait Ammar abandoned iron mine soil, Morocco. Ekológia 2016, 35, 32-49. [CrossRef]

14. Obiora, S.C.; Chukwu, A.; Davies, T.C. Heavy metals and health risk assessment of arable soils and food crops around $\mathrm{Pb}-\mathrm{Zn}$ mining localities in Enyigba, southeastern Nigeria. J. Afr. Earth Sci. 2016, 116, 182-189. [CrossRef]

15. Xue, S.; Shi, L.; Wu, C.; Wu, H.; Qin, Y.; Pan, W.; Hartley, W.; Cui, M. Cadmium, lead, and arsenic contamination in paddy soils of a mining area and their exposure effects on human HEPG2 and keratinocyte cell-lines. Environ. Res. 2017, 156, 23-30. [CrossRef] [PubMed]

16. Liu, J.; Wang, J.; Xiao, T.; Bao, Z.; Lippold, H.; Luo, X.; Yin, M.; Ren, J.; Chen, Y.; Linghu, W. Geochemical dispersal of thallium and accompanying metals in sediment profiles from a smelter-impacted area in South China. Appl. Geochem. 2018, 88, 239-246. [CrossRef]

17. Wu, J.; Long, J.; Liu, L.; Li, J.; Liao, H.; Zhang, M.; Zhao, C.; Wu, Q. Risk assessment and source identification of toxic metals in the agricultural soil around a $\mathrm{Pb} / \mathrm{Zn}$ mining and smelting area in Southwest China. Int. J. Environ. Res. Public Health 2018, 15, 1838. [CrossRef]

18. Wiggenhauser, M.; Bigalke, M.; Imseng, M.; Müller, M.; Keller, A.; Murphy, K.; Kreissig, K.; Rehkämper, M.; Wilcke, W.; Frossard, E. Cadmium isotope fractionation in soil-wheat systems. Environ. Sci. Technol. 2016, 50, 9223-9231. [CrossRef]

19. Dinis, L.; Savard, M.M.; Gammon, P.; Bégin, C.; Vaive, J. Influence of climatic conditions and industrial emissions on spruce tree-ring $\mathrm{Pb}$ isotopes analyzed at ppb concentrations in the Athabasca oil sands region. Dendrochronologia 2016, 37, 96-106. [CrossRef]

20. Wei, X.; Lyu, S.; Yu, Y.; Wang, Z.; Liu, H.; Pan, D.; Chen, J. Phylloremediation of air pollutants: Exploiting the potential of plant leaves and leaf-associated microbes. Front. Plant Sci. 2017, 28, 1318. [CrossRef]

21. Liu, J.; Wei, X.; Zhou, Y.; Tsang, D.C.W.; Bao, Z.; Yin, M.; Lippold, H.; Yuan, W.; Wang, J.; Feng, Y.; et al. Thallium contamination, health risk assessment and source apportionment in common vegetables. Sci. Total Environ. 2020, 703, 135547. [CrossRef] [PubMed]

22. Wang, J.; Jiang, Y.; Sun, J.; She, J.; Yin, M.; Fang, F.; Xiao, T.; Song, G.; Liu, J. Geochemical transfer of cadmium in river sediments near a lead-zinc smelter. Ecotoxicol. Environ. Saf. 2020, 196, 110529. [CrossRef] [PubMed] 
23. Durkalec, M.; Szkoda, J.; Kolacz, R.; Opalinski, S.; Nawrocka, A.; Zmudzki, J. Bioaccumulation of Lead, Cadmium and Mercury in Roe Deer and Wild Boars from areas with different levels of toxic metal pollution. Int. J. Environ. Res. 2015, 9, 205-212. [CrossRef]

24. Kapusta, P.; Sobczyk, Ł. Effects of heavy metal pollution from mining and smelting on enchytraeid communities under different land management and soil conditions. Sci. Total Environ. 2015, 536, 517-526. [CrossRef]

25. Weissmannová, H.D.; Pavlovský, J. Indices of soil contamination by heavy metals—Methodology of calculation for pollution assessment (minireview). Environ. Monit. Assess. 2017, 189, 616. [CrossRef]

26. Barbieri, M. The importance of enrichment factor (EF) and geoaccumulation index ( $\left.\mathrm{I}_{\text {geo }}\right)$ to evaluate the soil contamination. J. Geol. Geophys. 2016, 5, 237. [CrossRef]

27. Baran, A.; Wieczorek, J. Application of geochemical and ecotoxicity indices for assessment of heavy metals content in soils. Arch. Environ. Prot. 2015, 41, 54-63. [CrossRef]

28. Baran, A.; Wieczorek, J.; Mazurek, R.; Urbański, K.; Klimkowicz-Pawlas, A. Potential ecological risk assessment and predicting zinc accumulation in soils. Environ. Geochem. Health 2018, 40, 435-450. [CrossRef]

29. Wieczorek, J.; Baran, A.; Urbański, K.; Mazurek, R.; Klimowicz-Pawlas, A. Assessment of the pollution and ecological risk of lead and cadmium in soils. Environ. Geochem. Health 2018, 40, 2325-2342. [CrossRef]

30. Zang, Z.; Li, Y.; Li, H.; Guo, Z.; Zhang, R. Spatiotemporal variation and pollution assessment of Pb/Zn from smelting activities in China. Int. J. Environ. Res. Public Health 2020, 17, 1968. [CrossRef]

31. Mazurek, R.; Kowalska, J.B.; Gąsiorek, M.; Zadrożny, P.; Wieczorek, J. Pollution indices as comprehensive tools for evaluation of the accumulation and provenance of potentially toxic elements in soils in Ojców National Park. J. Geochem. Explor. 2019, 201, 13-30. [CrossRef]

32. Blaser, P.; Zimmermann, S.; Luster, J.; Shotyk, W. Critical examination of trace element enrichments and depletions in soils: As, Cr, Cu, Ni, Pb, and Zn in Swiss forest soils. Sci. Total Environ. 2000, 249, 257-280. [CrossRef]

33. Desaules, A. Critical evaluation of soil contamination assessment methods for trace metals. Sci. Total Environ. 2012, 426, 120-131. [CrossRef]

34. Wu, J.; Teng, Y.; Lu, S.; Wang, Y.; Jiao, X. Evaluation of soil contamination indices in a mining area of Jiangxi, China. PLoS ONE 2014, 9, e112917. [CrossRef]

35. Maanan, M.; Saddik, M.; Maanan, M.; Chaibi, M.; Assobhei, O.; Zourarah, B. Environmental and ecological risk assessment of heavy metals in sediments of Nador lagoon, Morocco. Ecol. Indic. 2015, 48, 616-626. [CrossRef]

36. Rachwał, M.; Kardel, K.; Magiera, T.; Bens, O. Application of magnetic susceptibility in assessment of heavy metal contamination of Saxonian soil (Germany) caused by industrial dust deposition. Geoderma 2017, 295, 10-21. [CrossRef]

37. Leach, D.L.; Viets, J.G.; Powell, J.W. Textures of ores from the Silesian-Cracow zinc-lead deposits, Poland: Clues to the ore-forming environment. Pol. Geol. Inst. Pap. 1996, 154, 37-50.

38. Szuwarzynski, M. Ore bodies in the Silesian-Cracow Zn-Pb ore district, Poland. Pol. Geol. Inst. Pap. 1996, 154, 9-24.

39. Górecka, E. Mineral sequence development in the $\mathrm{Zn}-\mathrm{Pb}$ deposits of the Silesian-Cracow area, Poland. Pol. Geol. Inst. Pap. 1996, 154, 37-50.

40. Molenda, D. Mining of Lead and Silver in the Silesia-Cracow Region Up to the Middle of the 16th Century; Ossolineum: Wrocław, Poland, 1963.

41. Panek, S. The History of Lead and Zinc Ore Mining in Jaworzno-Trzebinia-Chrzanow. Unpublished work, Jaworzno. 1995.

42. Cabala, J.; Sutkowska, K. Past exploitation and processing of $\mathrm{Zn}-\mathrm{Pb}$ ore influence on the industrial soil minerals composition. Olkusz and Jaworzno district. Pr. Nauk. Inst Górnictwa Polit Wroct Studia Mater. 2006, $117,13-22$.

43. Sutkowska, K.; Teper, L. Anthropogenic forms of urban post-mining landscape by example of Jaworzno. Prz. Górn. 2012, 68, 70-77. 
44. Teper, E. Dust-particle migration around flotation tailings ponds: Pine needles as passive samplers. Environ. Monit. Assess. 2009, 154, 383-391. [CrossRef] [PubMed]

45. Aleksander-Kwaterczak, U.; Helios-Rybicka, E. Contaminated sediments as a potential source of $\mathrm{Zn}, \mathrm{Pb}$, and $\mathrm{Cd}$ for a river system in the historical metalliferous ore mining and smelting industry area of South Poland. J. Soils Sediments 2009, 9, 13. [CrossRef]

46. Aleksander-Kwaterczak, U.; Ciszewski, D.; Szarek-Gwiazda, E.; Kwandrans, J.; Wilk-Woźniak, E.; Waloszek, A. The influence of historical activity of the $\mathrm{Zn}-\mathrm{Pb}$ ore mine in Chrzanów on the aquatic environment quality of the Matylda valley. Górnictwo Geol. 2010, 5, 21-30.

47. Chlopecka, A.; Bacon, J.R.; Wilson, M.J.; Kay, J. Forms of Cadmium, Lead and Zinc in contaminated soils from Southwest Poland. J. Environ. Qual. 1996, 25, 69-79. [CrossRef]

48. Cabala, J.; Teper, L. Metalliferous constituents of rhizosphere soils contaminated by $\mathrm{Zn}-\mathrm{Pb}$ mining in southern Poland. Water Air Soil Pollut. 2007, 178, 351-362. [CrossRef]

49. Sutkowska, K.; Teper, L.; Vaněk, A.; Czech, T.; Baran, A. Effect of historical zinc processing on soil: A case study in Southern Poland. In Proceedings of the 3rd World Congress on New Technologies (NewTech'17), Rome, Italy, 6-8 June 2017; p. 110. [CrossRef]

50. Vaněk, A.; Chrastný, V.; Teper, L.; Cabala, J.; Penížek, V.; Komárek, M. Distribution of thallium and accompanying metals in tree rings of Scots pine (Pinus sylvestris L.) from a smelter-affected area. J. Geochem. Explor. 2011, 108, 73-80. [CrossRef]

51. Pająk, M.; Halecki, W.; Gasiorek, M. Accumulative response of Scots pine (Pinus sylvestris L.) and silver birch (Betula pendula Roth) to heavy metals enhanced by $\mathrm{Pb}$-Zn ore mining and processing plants: Explicitly spatial considerations of ordinary kriging based on a GIS approach. Chemosphere 2017, 168, 851-859. [CrossRef]

52. Augustyniak, M.; Orzechowska, H.; Kędziorski, A.; Sawczyn, T.; Doleżych, B. DNA damage in grasshoppers' larvae-Comet assay in environmental approach. Chemosphere 2014, 96, 180-187. [CrossRef]

53. Dmowski, K.; Rossa, M.; Kowalska, J.; Krasnodębska-Ostręga, B. Thallium in spawn, juveniles, and adult common toads (Bufo bufo) living in the vicinity of a zinc-mining complex, Poland. Environ. Monit. Assess. 2015, 187, 4141. [CrossRef]

54. Kurek, S.; Sobczyński, P.; Szuwarzyński, M.; Wojnar, E. The characteristics of the Chrzanow region deposits. Pol. Geol. Inst. Pap. 1977, 45, 45-71.

55. Håkanson, L. An ecological risk index for aquatic pollution controls sediment logical approach. Water Res. 1980, 14, 975-1001. [CrossRef]

56. Tomlinson, D.L.; Wilson, J.G.; Harris, C.R.; Jeffrey, D.W. Problems in the assessment of heavy-metal levels in estuaries and the formation of a pollution index. Helgol. Wiss. Meeresunters. 1980, 33, 566-575. [CrossRef]

57. Zhang, C.; Qiao, Q.; Piper, D.; Huang, B. Assessment of heavy metal pollution from a Fe-smelting plant in urban river sediments using environmental magnetic and geochemical methods. Environ. Pollut. 2011, 159, 3057-3070. [CrossRef] [PubMed]

58. Müller, G. Index of geo-accumulation in sediments of the Rhine River. Geo. J. 1969, 2, 108-118.

59. Detailed Geochemical Map of Upper Silesia. Sheet: Sławków, Olkusz, Nowa Góra, Myślachowice, Chrzanów, Dabrowa Górnicza, Strzemieszyce, Jaworzno and Libiąz; Pasieczna, A., Ed.; Polish Geological Institute: Warszawa, Poland, 2008.

60. Lis, J.; Pasieczna, A. Geochemical Atlas of Upper Silesia 1:200,000; Publications of the Polish Geological Institute: Warszawa, Poland, 1995.

61. Salminen, R. (Ed.) Geochemical Atlas of Europe 2005 Part 1 and 2; Geol. Survey of Finland: Espoo, Finland, 2005.

62. Sutherland, R.A.; Tolosa, C.A.; Tack, F.M.G.; Verloo, M.G. Characterization of Selected Element Concentrations and Enrichment Ratios in Background and Anthropogenically Impacted Roadside Areas. Arch. Environ. Contam. Toxicol. 2000, 38, 428-438. [CrossRef] [PubMed]

63. Gupta, S.; Jena, V.; Matic, N.; Kapralova, V.; Solanki, J.S. Assessment of geo-accumulation index of heavy metal and source of contamination by multivariate factor analysis. Int. J. Hazard. Mater. 2014, 2, 18-22.

64. Szuszkiewicz, M.; Łukasik, A.; Magiera, T.; Mendakiewicz, M. Combination of geo- pedo- and technogenic magnetic and geochemical signals in soil profiles Diversification and its interpretation: A new approach. Environ. Pollut. 2016, 214, 464-477. [CrossRef]

65. Szuszkiewicz, M.; Petrovsky, E.; Łukasik, A.; Gruba, P.; Grison, H.; Szuszkiewicz, M.M. Technogenic contamination or geogenic enrichment in Regosols and Leptosols? Magnetic and geochemical imprints on topsoil horizons. Geoderma 2021, 381, 114685. [CrossRef] 
66. Kabata-Pendias, A.; Pendias, H. Biogeochemistry of Trace Elements; PWN: Warszawa, Poland, 1999.

67. Romero-Baena, A.J.; González, I.; Galán, E. Soil pollution by mining activities in Andalusia (South Spain)-The role of mineralogy and geochemistry in three case studies. J. Soils Sediments 2018, 18, 2231-2247. [CrossRef]

Publisher's Note: MDPI stays neutral with regard to jurisdictional claims in published maps and institutional affiliations.

(C) 2020 by the authors. Licensee MDPI, Basel, Switzerland. This article is an open access article distributed under the terms and conditions of the Creative Commons Attribution (CC BY) license (http://creativecommons.org/licenses/by/4.0/). 